\title{
The Health Service Ombudsman
}

\author{
R.A. Oswald
}

"We have no credibility". That was the response of a woman with a mental illness who put a complaint to the Health Service Ombudsman. Unlike many - not just patients but also a significant number of NHS staff - she had heard that the Ombudsman could carry out a completely independent investigation of complaints although she was not clear about the extent of his jurisdiction. Some people feel intimidated when trying to take on what they see as a powerful and defensive NHS and others experience a sense of despair that because of their illness their concerns have no validity. Those providing care and treatment generally do the best they can to attain high professional standards but delivery does not always match expectations and the outcome can be a complaint. Services for the mentally ill are not immune from shortcomings and, if local management fails to satisfy the complainant, the Ombudsman can step in.

The Office of Health Service Commissioner came into being in 1973. Parliament established three Offices of Ombudsman - one each for England, Scotland and Wales - although all are at present held by one person. The function of the Ombudsman is to investigate complaints that hardship or injustice has been caused to an individual as a consequence of maladministration, a failure in service or a failure to provide a service which there is a duty to provide. Most lapses in care are caused by a breakdown in communications between staff and patients or relatives, or between different members of the clinical team. Increasing emphasis on team work, and on each member of the team having a particular contribution to make, means that it has never been more important for there to be a shared understanding of the plan of care, and for all to agree what is to be done, when and by whom. There are many cases in the Ombudsman's files of breakdowns in the supervision of disturbed patients, failure to explain the treatment being given, or lack of information to carers because staff make wrong assumptions or do not pass on the information - orally or in writing - to colleagues.

The Ombudsman is completely independent of government and the NHS and is accountable to Parliament. His powers are set out in the Health
Service Commissioners Act 1993, which brought together the provisions of earlier statutes. The Ombudsman has the powers of the High Court to require any person he considers may be able to supply relevant information to give oral evidence or provide documents, including the clinical records. In reality it is very rare for those powers to have to be used and staff, members of the public and others generally co-operate fully in an investigation. Any member of staff who is to be interviewed will have been provided with a summary of the matters subject to investigation and notes of guidance for witnesses: one important provision is the right to be accompanied by a person of the witness's choosing, such as a friend or a representative of a professional body or defence organisation.

Any complaint to the Ombudsman must be made in writing, and accompanied by any previous correspondence and evidence to support the matter complained about. The Ombudsman must be satisfied that the complaint has first been put to the responsible authority, board or trust. Normally a complaint should be made to the Ombudsman within 12 months of the events at issue, although that time limit can be waived if it seems reasonable to do so (such as where local management was dilatory in its own handling of the complaint, or it is likely that recollections will be reasonably fresh).

There are matters which Parliament has excluded from the Ombudsman's jurisdiction. These include personnel matters - it is no good coming to him about staff appointments, gradings or discipline-and where the aggrieved person has gone, or could go, to court. The Ombudsman's services are entirely free to the complainant (although not to the tax-payer!), and he is not there to provide a no-cost research service for potential litigants who believe there has been negligence and want compensation. Sometimes a complainant will use words such as negligence out of anger and with no legal intent, and the Ombudsman may well go ahead if he obtains the necessary assurances. He is also unable to look into the actions of general practitioners or matters which in his opinion arise from the exercise of clinical judgement. Many perceive that as a major drawback to the effectiveness of his Office, but he often finds that a 
failure in service or care is attributable not to the clinical decision itself but to its execution. There may have been fallure in communication, insensitive attitudes, or a failure to follow - or even a complete absence of - procedure. He will usually wish to see the clinical records in order to put the complaint in context.

Who can bring a complaint to the Ombudsman? Where the person directly affected is unable to make the complaint, someone else can represent that person. Usually that will be the next-of-kin, and the Ombudsman will need to be satisfied that, where the patient is competent, he or she is in support of the complaint. The need to respect the rights and dignity of mentally ill people means that the credentials of any advocate have to be satisfactory. It may also be necessary to check sensitively that a complaint is not a manifestation of illness, although there are dangers here - hence the quotation which opened this article. For a similar reason, before issuing his report to the complainant and the NHS authority concerned, the Ombudsman may ask for clinical advice as to whether its contents are likely to be detrimental to the patient's well-being.

Primarily as a consequence of the 'scandals' of the 1960s (such as Ely and South Ockendon) Parliament decided to provide from the outset for members of staff to be able to bring to the Ombudsman a complaint about the care provided to a particular patient. The Ombudsman needs to be satisfied that there is no-one else such as a close relative - better able to represent the patient though there may be no close relatives or friends to act as advocate. For complaints brought by members of staff it is not mandatory for the matter first to have been put to the responsible authority. The person complaining must provide evidence in support of the allegation, which must be about the care or treatment of an identified individual. The Ombudsman cannot look into generalised complaints about levels of service or lack of resources. Dissatisfaction with a discretionary decision taken by a NHS authority - about, for example, the level of care to be provided - does not constitute evidence of maladministration: there must have been shortcomings in the decision-making process. Surprisingly, few NHS staff seem aware of their right to approach the Ombudsman.
The Ombudsman reaches his findings on the balance of probabilities, rather than on the criminal law test of 'beyond reasonable doubt'. He usually upholds around $60 \%$ of the grievances accepted by him for investigation. Most complainants are looking for an apology and for assurance that the same thing will not happen to others. When the Ombudsman upholds a complaint he usually recommends remedial action such as preparation of clarification of guidance. or issue of a reminder or instruction to staff - by the NHS authority complained against. A check is always made that the agreed action has been carried out, and it is extremely rare for a recommendation not to be accepted, not the least because refusal can result in an appearance before the Select Committee of Parliament which oversees the Ombudsman's work.

Every six months a volume of selected investigation reports is published through HMSO, the aim being to impart to the NHS the lessons to be learnt from the cases in question. The name of the complainant, and of individual members of staff, is not disclosed but no secrecy surrounds the identity of the NHS authority, board or trust or of the hospital or clinic in question. These volumes, and the Ombudsman's annual report in which themes or key issues are identified, are a rich source of material about how individual users of the NHS perceive the service they have received, and what problems can arise. As an independent and exhaustive auditor of care, the Ombudsman's published volumes should be studied if for no other reason than that of cool self interest. It is much better to learn from the experience of others than from perpetrating avoidable mistakes. Getting things right in the first place must be the overriding aim of everyone delivering care, and in that way staff can hope to avoid the rigorous attentions of the Ombudsman and his investigating officers and, where a case raises particularly serious issues or matters of public interest, a searching appearance in Parliament before the Select Committee.

R.A. Oswald, Office of the Health Service Commissioner for England (Ombudsman). Church House, Great Smith Street, London SWIP 3BW 